Energy Research Journal 1 (2): 146-151, 2010

ISSN 1949-0151

(C) 2010 Science Publications

\title{
The Thermo-Economics Analysis of the Optimum Thickness of Double-Layer Insulation for Air Conditioning Duct
}

\author{
${ }^{1} \mathrm{~N}$. Soponpongpipat, ${ }^{1} \mathrm{P}$. Jaruyanon and ${ }^{2} \mathrm{~S}$. Nanetoe \\ ${ }^{1}$ Department of Mechanical Engineering, \\ ${ }^{2}$ Department of Industrial Engineering and Management, \\ Faculty of Engineering and Industrial Technology, Silpakorn University, Thailand 73000
}

\begin{abstract}
Problem statement: Engineering economics played an important role in engineering design works. The net saving value was the easiest criterion to indicate the optimum design. However, the information about the net saving analysis of double-layer insulation of air conditioning duct was insufficient. Thus, it was important to study this case. Approach: The optimum thickness analysis of air conditioning duct's insulation, which composes of the layer of rubber and fiber glass insulator, was conducted by means of thermo-economics method. In addition, the effects of heat transfer coefficient at inside and outside of duct on the optimum thickness of these insulators were also studied. The research was done by considering the insulation's optimum thickness of circular galvanized steel duct. The duct diameter of $0.5 \mathrm{~m}$ with rubber insulator $\left(\mathrm{k}=0.035 \mathrm{~W} \mathrm{~m}^{-1} \mathrm{~K}^{-1}\right)$ and fiber glass insulator $\left(\mathrm{k}=0.045 \mathrm{~W} \mathrm{~m}^{-1} \mathrm{~K}^{-1}\right)$ was selected to show the study results. In order to study the change in optimum thickness when convective heat transfer coefficients were varied, the inside and outside duct convective heat transfer coefficient of $6,10,14,18$ and $22 \mathrm{~W} \mathrm{~m}^{-2} \mathrm{~K}^{-1}$ were selected for calculation of optimum thickness. Results: The results showed that the variation of inside and outside duct's heat transfer coefficient did not affect on the insulator's optimum thickness. In the case of a circular duct of $0.5 \mathrm{~m}$ in diameter and the inside and outside convective heat transfer coefficient of 6 and $22 \mathrm{~W} \mathrm{~m}^{-2} \mathrm{~K}^{-1}$ respectively, the optimum thickness was 0.0032 and $0.125 \mathrm{~m}$ for rubber and fiber glass insulator respectively. The net saving was 34,173.00 Baht per meter of duct. Conclusion: Finally, when the consideration in terms of insulator cost was done, the thermo-economics analysis of optimum thickness of double-layer insulation was recommended when the cost of main insulator was higher than that of auxiliary insulator otherwise the thermo-economics analysis of optimum thickness of single-layer insulation was sufficient. In addition, the variation of inside and outside duct convective heat transfer coefficient did not affect the optimum thickness. But net saving increased when inside and outside duct convective heat transfer coefficient increased.
\end{abstract}

Key words: Thermo-economics, optimum thickness, duct insulation, net saving

\section{INTRODUCTION}

In a present day, the economical design is an important issue in thermal engineering work. The optimum design, minimum cost and high efficiency, is the necessary requirement. In order to fulfill this requirement, there are many works tried to find out the criteria for the optimum design (Umberto et al., 2009; Nelson et al., 2009; David et al., 2009; Soylemez, 2001a; 2001b). In case of thermal insulation, many works deal with the optimum thickness of insulation, both in building wall (Jinghua et al., 2009; Ozel and Pihtili, 2007; Bolatturk, 2006) and refrigeration application
(Soylemez and Unsal, 1999). Although there are many concepts for finding the optimum point, the simplest concept was introduced by Soylemez and Unsal (1999). They showed that the net saving value was the easiest criterion to indicate the optimum point. In addition, they showed the calculation method of optimum insulation thickness for single-layer insulation in refrigeration applications. However, we can see that there is a difference in cost of various types of insulator. In some case, a mixed insulation, the use of more than one type of insulator, may be more suitable. For example, the cost of rubber insulator is higher than that of the fiber glass insulator but we select the rubber

Corresponding Author: N. Soponpongpipat, Department of Mechanical Engineering, Faculty of Engineering and Industrial Technology, Silpakorn University, Thailand 73000 Tel: +66-34-259025 Fax: +66-34-219367 
insulator in refrigeration and air conditioning application to avoid wetting inside insulator due to condensation of air's moisture at the cold surface. In this case, if the thickness of rubber insulator is enough to prevent condensation, we can use the fiber glass insulator as adjacent insulator layer to reduce heat flow into the duct instead of the use of only rubber insulator. According to above example, we called, in this study, the rubber insulator as main insulator and the fiber glass insulator as auxiliary insulator. Unfortunately, the information about the optimum point of insulation system that consists of various layers of insulator materials is insufficient. Thus, this study will consider the optimum thickness of air conditioning's duct insulation which consists of the layer of rubber and fiber glass insulator by using maximum net saving criterion. Moreover, the variation of optimum thickness, when the convective heat transfer coefficients at inside and outside of duct were changed, was also investigated.

\section{MATERIALS AND METHODS}

\section{Mathematical model:}

Thermal calculation: Figure 1 shows the cross section area and thermal resistances of the bare air conditioning duct. The amount of radius heat flow into the duct $\left(Q_{\text {bare duct }}\right)$ can be calculated by the following Eq. 1:

$$
\mathrm{Q}_{\text {bare duct }}=\frac{\Delta \mathrm{T}}{\mathrm{Z}_{\text {total, bare duct }}}
$$

Temperature difference between the outside and inside of duct $(\Delta \mathrm{T})$ can be found by:

$$
\Delta \mathrm{T}=\mathrm{T}_{\mathrm{o}, \text { mean }}-\mathrm{T}_{\mathrm{i}, \mathrm{mean}}
$$

Total thermal resistances $\left(\mathrm{Z}_{\text {total,bare duct }}\right)$, in case of bare duct, can be determined by summation of inner duct thermal resistance due to heat convection $\left(Z_{1}\right)$, thermal resistance due to heat conduction in duct material $\left(Z_{2}\right)$ and thermal resistance due to outer heat convection $\left(Z_{3}\right)$ :

$$
\mathrm{Z}_{\text {total, bare duct }}=\frac{1}{\mathrm{~h}_{\mathrm{i}} \mathrm{A}_{\mathrm{i}}}+\frac{\ln \left(\frac{\mathrm{R}_{\mathrm{o}, \text { duct }}}{\mathrm{R}_{\mathrm{i} \text {,duct }}}\right)}{2 \pi \mathrm{L}_{\text {duct }} \mathrm{k}_{\text {duct }}}+\frac{1}{\mathrm{~h}_{\mathrm{o}} \mathrm{A}_{\mathrm{o}}}
$$

Where:

$$
\mathrm{A}_{\mathrm{i}}=2 \pi \mathrm{R}_{\mathrm{i} \text {,duct }} \mathrm{L}_{\text {duct }}
$$

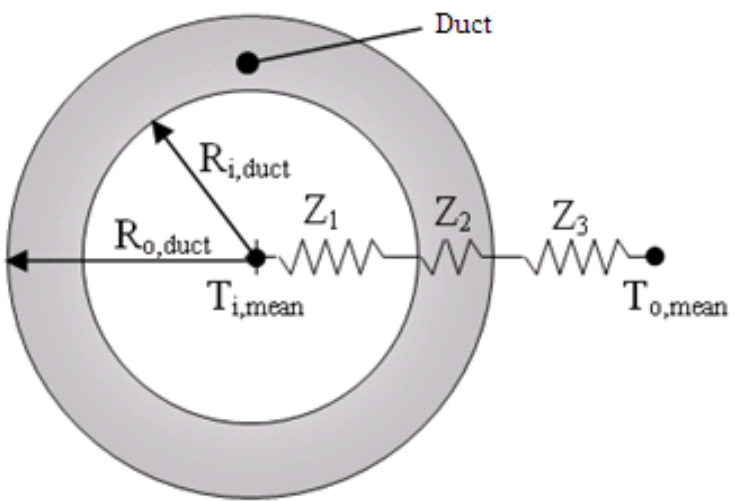

Fig. 1: The cross section area and thermal resistances of the bare air conditioning duct

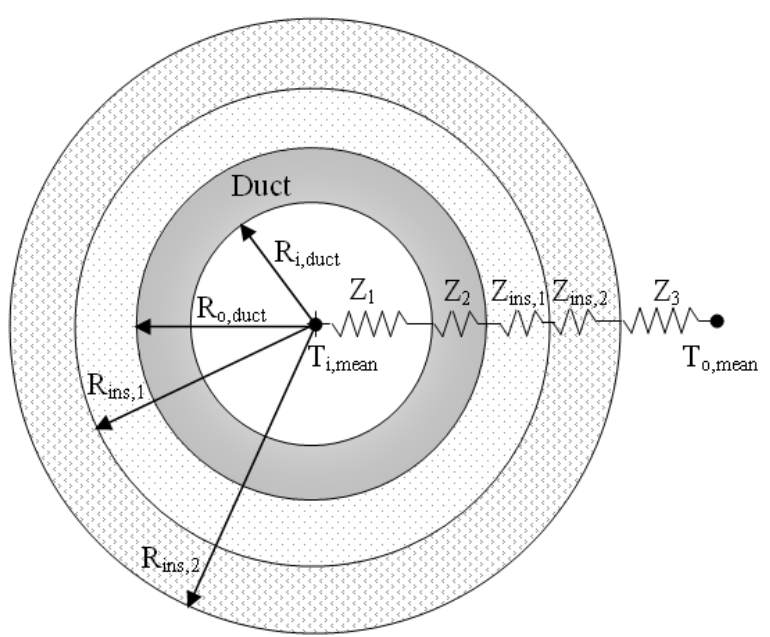

Fig. 2: The thermal resistance in case of an insulated duct with rubber insulator as inner insulator layer and fiber glass insulator as outer insulator layer

$\mathrm{A}_{\mathrm{o}}=2 \pi \mathrm{R}_{\mathrm{o}, \text { duct }} \mathrm{L}_{\text {duct }}$

In case of insulated duct with rubber insulator as inner insulator layer and fiber glass insulator as outer insulator layer, the thermal resistance was shown in Fig. 2. The radius heat flow in this case $\left(Q_{\text {ins duct }}\right)$ can be determined by the following Eq. 6:

$$
\mathrm{Q}_{\text {ins duct }}=\frac{\Delta \mathrm{T}}{\mathrm{Z}_{\text {total, Ins duct }}}
$$

Total thermal resistances $\left(Z_{\text {total,Ins duct }}\right)$, in case of insulated duct, can be determined by summation of $Z_{1}$, $Z_{2}$, thermal resistance of inner insulator layer $\left(Z_{\text {ins, } 1}\right)$, thermal resistance of outer insulator layer $\left(Z_{\text {ins, } 2}\right)$ and $Z_{3}$ : 
Energy Rec. J. 1 (2): 146-151, 2010

$$
\begin{aligned}
\mathrm{Z}_{\text {total ins duct }}= & \frac{1}{\mathrm{~h}_{\mathrm{i}} \mathrm{A}_{\mathrm{i}}}+\frac{\ln \left(\frac{\mathrm{R}_{\mathrm{o}, \text { duct }}}{\mathrm{R}_{\mathrm{i}, \text { duct }}}\right)}{2 \pi \mathrm{L}_{\text {duct }} \mathrm{k}_{\text {duct }}}+\frac{\ln \left(\frac{\mathrm{R}_{\text {ins }, 1}}{\mathrm{R}_{\mathrm{o} \text {,duct }}}\right)}{2 \pi \mathrm{L}_{\text {duct }} \mathrm{k}_{\text {ins }, 1}} \\
& +\frac{\ln \left(\frac{\mathrm{R}_{\text {ins }, 2}}{\mathrm{R}_{\text {ins }, 1}}\right)}{2 \pi \mathrm{L}_{\text {duct }} \mathrm{k}_{\text {ins }, 2}}+\frac{1}{\mathrm{~h}_{\mathrm{o}} \mathrm{A}_{\mathrm{o}}}
\end{aligned}
$$

The amount of heat flow, which can be decreased by insulation, can be found by following Eq. 8:

$$
\mathrm{Q}_{\text {save }}=\mathrm{Q}_{\text {bare duct }}-\mathrm{Q}_{\text {ins duct }}
$$

Net saving calculation: The net Saving ( $S$ ) is a function of the difference between the cost of saving energy and the cost of materials, installation, operation and resale value, by:

$$
\begin{aligned}
\mathrm{S}= & \frac{\mathrm{P}_{1} \mathrm{C}_{\mathrm{E}} \mathrm{Q}_{\text {save }} \Delta \mathrm{t}}{\mathrm{COP}}-\mathrm{P}_{2}\left[\left(\mathrm{C}_{\mathrm{ins}, 1} \mathrm{~A}_{\text {ins }, 1} \mathrm{x}_{\mathrm{ins}, 1}+\mathrm{C}_{\text {ins }, 2} \mathrm{~A}_{\text {ins }, 2} \mathrm{x}_{\text {ins }, 2}\right)\right. \\
& \left.+\mathrm{C}_{\text {install }, 1} \mathrm{~A}_{\text {ins }, 1}+\mathrm{C}_{\text {install }, 2} \mathrm{~A}_{\text {ins }, 2}\right]
\end{aligned}
$$

Where:

$$
\begin{aligned}
& \mathrm{C}_{\mathrm{E}} \quad=\text { Energy cost }\left(\text { Baht } \mathrm{kWh}^{-1}\right) \\
& \Delta \mathrm{t} \quad=\text { Operation time of air conditioning } \\
& \text { system (h) } \\
& \mathrm{COP}=\text { Coefficient of Performance } \\
& \mathrm{C}_{\mathrm{ins}, 1} \text { and } \mathrm{C}_{\mathrm{ins}, 2} \quad=\text { Materials cost of inner and outer } \\
& \text { insulator (Baht } \mathrm{m}^{-3} \text { ) } \\
& \mathrm{A}_{\mathrm{ins}, 1} \text { and } \mathrm{A}_{\mathrm{ins}, 2}=\text { Area of inner and outer insulator } \\
& \left(\mathrm{m}^{2}\right) \\
& \mathrm{x}_{\mathrm{ins}, 1} \text { and } \mathrm{x}_{\mathrm{ins}, 2}=\text { Thickness of inner and outer } \\
& \text { insulator }(\mathrm{m}) \\
& \mathrm{C}_{\text {install, }, 1} \text { and } \mathrm{C}_{\text {install, }, 2}=\text { Installation cost of inner and outer } \\
& \text { insulator }\left(\mathrm{Baht}^{-2}\right) \\
& \mathrm{P}_{1} \text { and } \mathrm{P}_{2} \quad=\text { Calculated by: }
\end{aligned}
$$

Where:

$\mathrm{i}$ and $\mathrm{d}=$ Interest and inflation rate

$\mathrm{N}=$ Life cycle period of insulator

$\mathrm{M}_{\mathrm{s}} \quad=$ Ratio of maintenance and operation cost to initial cost

$\mathrm{R}_{\mathrm{v}} \quad=$ Ratio of resale value to initial cost

\begin{tabular}{|c|c|c|}
\hline Item & Description & Value \\
\hline 1 & Duct diameter & $0.5 \mathrm{~m}$ \\
\hline 2 & Thermal conductivity of duct & $60.5 \mathrm{~W} \mathrm{~m}^{-1} \mathrm{~K}^{-1}$ \\
\hline 3 & Thermal conductivity of rubber insulator & $0.035 \mathrm{~W} \mathrm{~m}^{-1} \mathrm{~K}^{-1}$ \\
\hline 4 & Thermal conductivity of fiber glass insulator & $0.045 \mathrm{~W} \mathrm{~m}^{-1} \mathrm{~K}^{-1}$ \\
\hline 5 & Inside duct convective heat transfer coefficient & $6 \mathrm{~W} \mathrm{~m}^{-2} \mathrm{~K}^{-1}$ \\
\hline 6 & Outside duct convective heat transfer coefficient & $22 \mathrm{~W} \mathrm{~m}^{-2} \mathrm{~K}^{-1}$ \\
\hline 7 & Temperature difference between inside and outside of duct & $13^{\circ} \mathrm{C}$ \\
\hline 8 & Interest rate & $14.25 \%$ \\
\hline 9 & Inflation rate & $2.1 \%$ \\
\hline 10 & Life cycle period of insulator & 10 years \\
\hline 11 & Ratio of maintenance and operation cost to initial cost & 0 \\
\hline 12 & Ratio of resale value to initial cost. & 0 \\
\hline 13 & Energy cost & 2.978 Baht kWh ${ }^{-1}$ \\
\hline 14 & Rubber insulator cost & $40697 \mathrm{Baht} \mathrm{m}^{-3}$ \\
\hline 15 & Fiber glass insulator cost & 5927.20 Baht $\mathrm{m}^{-3}$ \\
\hline 16 & Installation cost of rubber insulator & 270 Baht $\mathrm{m}^{-2}$ \\
\hline 17 & Installation cost of fiber glass insulator & $110 \mathrm{Baht} \mathrm{m}^{-2}$ \\
\hline 18 & Operation hours of air conditioning system & 23,040 h years $^{-1}$ \\
\hline 19 & Average COP & 2.81 \\
\hline
\end{tabular}

The positive sign of net saving implies that the insulation of duct gives benefits. In contrast, the negative sign means that the insulation of duct is worthless. In fact, the best design occurs when the net saving is highest. The insulation thickness that corresponds to the highest net saving is called the optimum thickness. Calculation of Eq. 9 cooperated with graphical method is the most suitable method to find the optimum thickness. The detail will discuss as follows.

\section{RESULTS}

Case study: In order to verify the assumption that the net saving of double-layer of insulation is higher than that of the single-layer insulation, the case study will be selected. The information of case study is shown in Table 1.

Table 1: The information of case study 
Figure 3 shows the calculation results of net saving of above information. The vertical axis shows net saving in Baht $\mathrm{m}^{-1}$ of duct after 23,040 h of operation. The primary horizontal axis displays the rubber insulator thickness in meters and the secondary horizontal axis shows the fiber glass insulator thickness in meters. We can see that if we use only rubber insulator for duct insulation, the optimum thickness of rubber insulator is $0.05 \mathrm{~m}$ and the net saving of this thickness is $30,201 \mathrm{Baht} \mathrm{m}^{-1}$ of duct. In the other hand, if we use rubber and fiber glass insulator for duct insulation, the optimum thickness of rubber and fiber glass insulator is 0.0032 and $0.125 \mathrm{~m}$, respectively. The net saving is $34,173 \mathrm{Baht} \mathrm{m}^{-1}$ of duct.

The effect of inside duct convective heat transfer coefficient on optimum thickness: Figure 4 shows the effect of inside duct convective heat transfer coefficient on optimum thickness. Figure 4 indicated that, although the inside duct convective heat transfer coefficient was varied from $6-22 \mathrm{~W} \mathrm{~m}^{-2} \mathrm{~K}^{-1}$, the optimum thickness of fiber glass and rubber insulator was constant at 0.125 and $0.0032 \mathrm{~m}$ respectively.

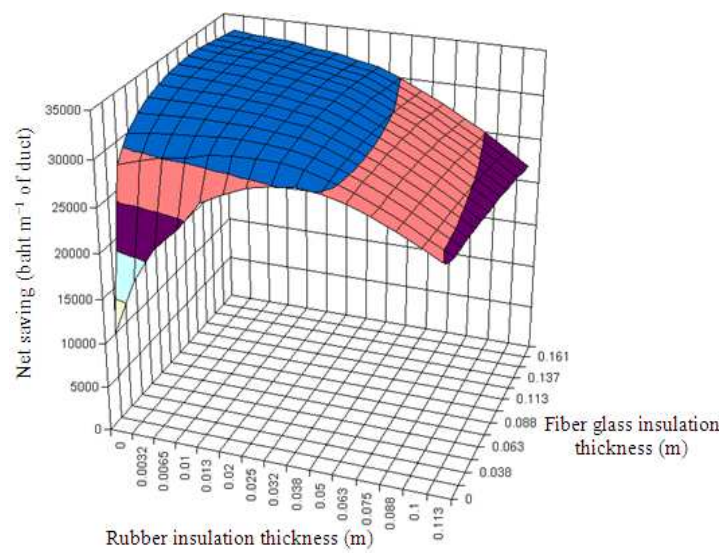

Fig. 3: The calculation results of net saving of the case study

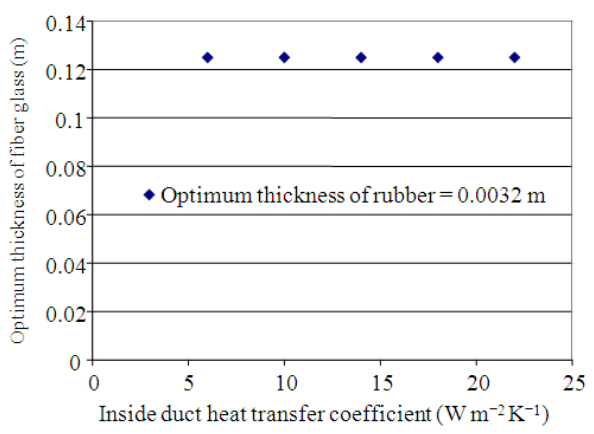

Fig. 4: The effect of inside duct convective heat transfer coefficient on optimum thickness
It should be noted from Fig. 5 that when inside duct convective heat transfer coefficient is increased from 6$22 \mathrm{~W} \mathrm{~m}^{-2} \mathrm{~K}^{-1}$, the net saving increases from 34,172 -

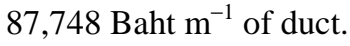

The effect of outside duct convective heat transfer coefficient on optimum thickness: Figure 6 shows the effect of outside duct convective heat transfer coefficient on optimum thickness. Figure 6 indicated that, although the outside duct convective heat transfer coefficient was varied form $6-22 \mathrm{~W} \mathrm{~m}^{-2} \mathrm{~K}^{-1}$, the optimum thickness of fiber glass and rubber insulator was constant at 0.125 and $0.0032 \mathrm{~m}$ respectively. Figure 7 shows that when outside duct convective heat transfer coefficient is increased from $6-22 \mathrm{~W} \mathrm{~m}^{-2} \mathrm{~K}^{-1}$, the net saving increases from $19,675-34,172$ Baht $^{-1}$ of duct.

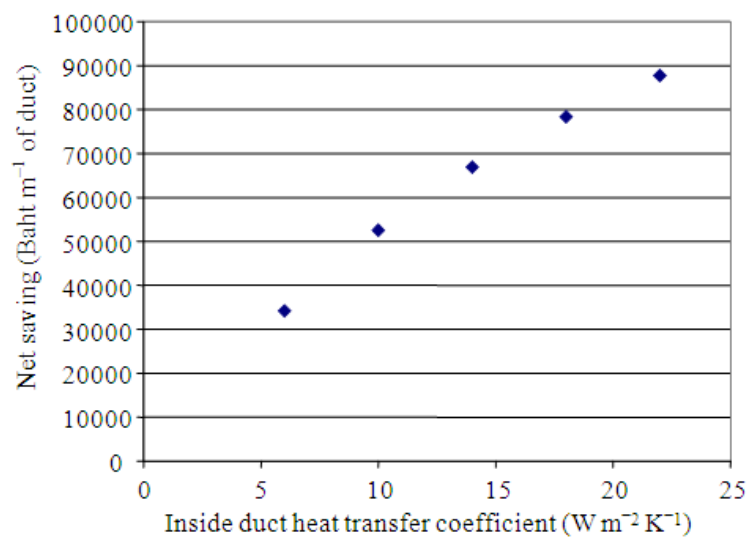

Fig. 5: The relationship between net saving and inside duct convective heat transfer coefficient

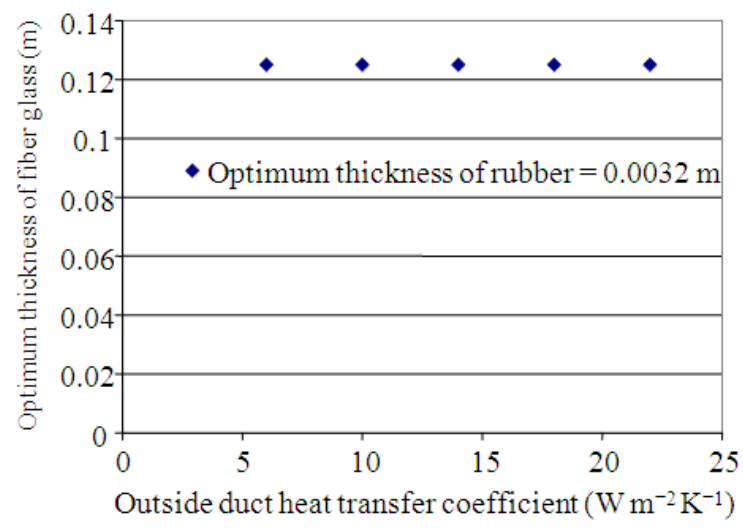

Fig. 6: The effect of outside duct convective heat transfer coefficient on optimum thickness 


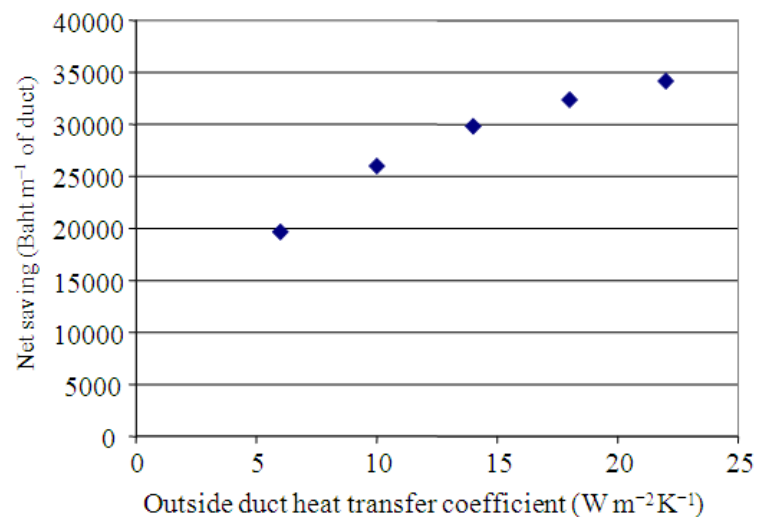

Fig. 7: The relationship between net saving and outside duct convective heat transfer coefficient

\section{DISCUSSION}

Case study: The result from Fig. 3 shows that the net saving of double-layer insulation is higher than that of only rubber insulation. In contrast, the net saving of double-layer insulation is lower than that of only fiber glass insulation. Thus, if the fiber glass insulator is suitable for a given application without the technical problems, the determination of optimum thickness by thermo-economics analysis of single layer is sufficient. This is because the materials cost of fiber glass is extremely lower than that of rubber insulator. From above discussion, it can be concluded that when we consider in term of materials costs, the thermoeconomics analysis of optimum thickness of doublelayer insulation is recommend when the cost of main insulator is higher than that of auxiliary insulator otherwise the thermo-economics analysis of optimum thickness of single-layer insulation is sufficient.

The effect of inside duct convective heat transfer coefficient on optimum thickness: We can clearly see from the Fig. 4 that the variation of inside duct convective heat transfer coefficient does not affect on optimum thickness. This means that the designer have not to concentrate on the uncertainty of convective heat transfer coefficient in real application. However, Fig. 5 shows that when inside duct convective heat transfer coefficient is increased, the net saving increases. This means that if the pay back period is a serious design criterion, the precision value of convective heat transfer coefficient is needed. Thus it can be concluded that the variation of inside duct convective heat transfer coefficient does not affect optimum thickness.
The effect of outside duct convective heat transfer coefficient on optimum thickness: We can clearly see form Fig. 6 that the variation of outside duct convective heat transfer coefficient does not affect optimum thickness. Figure 7 shows that when outside duct convective heat transfer coefficient is increased, the net saving increases. As same as discuss in above topic, when the pay back period is a serious design criterion, the precision value of convective heat transfer coefficient is needed. Thus it can be concluded that the variation of outside duct convective heat transfer coefficient does not affect optimum thickness.

\section{CONCLUSION}

When the consideration in terms of insulator cost was done, the thermo-economics analysis of optimum thickness of double-layer insulation is recommended when the cost of main insulator is higher than that of auxiliary insulator otherwise the thermo-economics analysis of optimum thickness of single-layer insulation is sufficient.

The variation of inside and outside duct convective heat transfer coefficient does not affect optimum thickness. But net saving increases when inside and outside duct convective heat transfer coefficient increases.

\section{ACKNOWLEDGEMENT}

The authors would like to thank Department of Mechanical Engineering, Faculty of Engineering and Industrial Technology, Silpakorn University for all support to this study.

\section{REFERENCES}

Bolatturk, A., 2006. Determination of optimum insulation thickness for building walls with respect to various fuels and climate zones in Turkey. Applied Therm. Eng., 26: 1301-1309. DOI: 10.1016/j.applthermaleng.2005.10.019

David, B., M. Gassner, T. Fuchino and F. Marechal, 2009. Thermo-economic analysis for the optimal conceptual design of biomass gasification energy conversion systems. Applied Therm. Eng., 29: 2137-2152. DOI: $10.1016 /$ j.applthermaleng.2007.06.021

Jinghua, Y., C. Yang, L. Tian and D. Liao, 2009. A study on optimum insulation thicknesses of external walls in hot summer and cold winter zone of China. Applied Energy, 86: 2520-2529. DOI: 10.1016/j.apenergy.2009.03.010 
Umberto, D., S. Proietti and P. Sdringola, 2009. Solarpowered cooling systems: Technical and economic analysis on industrial refrigeration and airconditioning applications. Applied Energy, 86: 1376-1386.

10.1016/j.apenergy.2009.01.011

Nelson, F., P.J. Mago and L.M. Chamra, 2009. Energy and economic evaluation of cooling, heating and power systems based on primary energy. Applied Thermal Eng., 29: 2665-2671. DOI: 10.1016/j.applthermaleng.2008.12.027

Ozel, M. and K. Pihtili, 2007. Optimum location and distribution of insulation layers on building walls with various orientations. Build. Environ., 42: 3051-3059. DOI: 10.1016/j.buildenv.2006.07.025
Soylemez, M.S. and M. Unsal, 1999. Optimum insulation thickness for refrigeration applications. Energy Convers. Manage., 40: 13-21. DOI: 10.1016/S0196-8904(98)00125-3

Soylemez, M.S., 2001a. On the optimum sizing of cooling towers. Energy Convers. Manage., 42: 783-789. DOI: 10.1016/S0196-8904(00)00148-5

Soylemez, M.S., 2001b. On the optimum channel sizing for HVAC systems. Energy Convers. Manage., 42: 791-798. DOI: 10.1016/S0196-8904(00)00149-7 